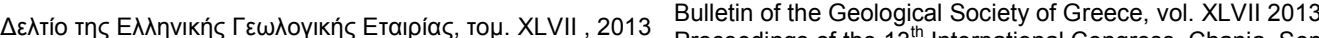
Proceedings of the $13^{\text {th }}$ International Congress, Chania, Sept.

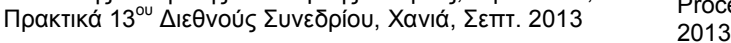

\title{
PETROGRAPHY AND ZIRCON MORPHOLOGY OF SYN- TECTONIC GRANITOIDS ROCKS OF HAFAFIT AREA, SOUTH EASTERN DESERT (EGYPT)
}

\author{
Thabet I. ${ }^{1 \&}{ }^{2}$, Kilias A. ${ }^{2}$, Koroneos A. ${ }^{3}$ and Kamh S. ${ }^{1}$ \\ ${ }^{1}$ Geology Department, Faculty of Science, Tanta University, Tanta, Egypt. \\ eslam642004@yahoo.com.,kilias@geo.auth.gr,koroneos@geo.auth.gr,kamh2002@yahoo.com. \\ ${ }^{2}$ Geology and Palaeontology Department, School of Geology, Aristotle University of Thessaloniki, \\ Greece. \\ ${ }^{3}$ Department of Mineralogy, Petrology and Economic Geology, School of Geology, Aristotle \\ University of Thessaloniki, Greece.
}

\begin{abstract}
The study deals with the petrography of the granitoid rocks intruding the five (A to E) domes of Hafafit Culmination. The morphological characteristics of zircon crystals are also examined, in order to elucidate the genesis of zircon and their host Hafafit granitoids. The granitoid rocks are tonalites, granodiorites and quartz diorites, all exhibiting gneissic texture. The zircon crystals from all the rock types intruding each one of the domes are examined in detail for colour, inclusions, crystal length, crystal width, elongation ratio, crystal form and habit, degree of roundness and corrosion, and are distinguished in groups on the basis of the previous characteristics. Two generations of zircons have been recognized; the first generation with magmatic features and the second one with post magmatic features. The first generation of zircon is attributed to the subduction, magmatic and deformation events while the second generation of zircon is attributed to metamorphism.
\end{abstract}

Key words: Wadi Hafafit Culmination, Morphological parameters, evolution events.

\section{Introduction}

The Hafafit domal structure (Wadi Hafafit Culmination, WHC) represents the largest antiformal structure in the Nubian Shield. It is considered to be of the most spectacular structures in the Eastern Desert, but its structural history has not been entirely clarified. The WHC has been subdivided into the eastern unit (Nugrus unit) which is composed mainly of low grade mica-schists and metavolcanics. This unit is associated with remnants of ophiolitic altered ultramafic rocks and metagabbros.

The western unit (Hafafit unit) has been subdivided into five separated gneissic domes (labeled AE core gneisses; of various extends (El Ramly and Greiling, 1988) (Figure 1). The cores of all domes are intruded by tonalities and granodiorites which were considered to be the youngest rocks within the Hafafit succession (Greiling et al., 1988b; Rashwan, 1991). El Bahariya and Abd El Wahed (2003) considered the granitoid-diorite cores together with the genetically related foliated 
metagabbro to represent the oldest intrusive rocks in the Hafafit area. The tectonic evolution of Hafafit culmination has been interpreted as a result of fold interference patterns involving multiply deformed sheath folds (Fowler and El Kalioubi, 2002) or as a consequence of tectono-magmatic and tectono-metamorphic processes in an active continental margin tectonic setting (El Bahariya and Abd El Wahed, 2003). The structural characteristics of the northern dome (dome A) of WHC, field descriptions of the dome and the surrounding rocks are discussed by Shalaby (2009) emphasizing to their relations with the overlying Pan-African cover nappes and the bounding ductile shear zones. He suggested that the emplacement of gneissic core occurred during accretion of the Pan-African nappes; later strike-slip shear zones of Najd Fault System and the associated Subsidiary shear arrays postdate the emplacement of the dome. In order to put some constraints on the petrogenesis of the migmatitic rock association, of the domes $\mathrm{B}$ and $\mathrm{C}$, as well as the tectonic processes which accompanied metamorphism and orogenesis, El Bahariya (2008) studied the P-T conditions of the different mineral assemblages and he estimated $\mathrm{P}=5 \mathrm{~kb}$ and $\mathrm{T}=750{ }^{\circ} \mathrm{C}$. It is to note that there are no tectonic or petrological data for domes $\mathrm{D}$ and $\mathrm{E}$.

Four tectonic models were proposed to explain the exhumation of WHC and to decipher their origin: (1) development of fault-bend fold "antiformal stacks" (e.g. Hafafit domal structure; Greiling et al.,1988a), (2) orogen-parallel crustal extension (e.g. HaFafit, Sibai and Meatiq domal structures; Wallbrecher et al., 1993; Fritz et al., 1996,2002; Bregar et al.,2002; Loizenbauer et al., 2001; Abdel Wahed, 2008; Khudeir et al., 2008), (3) emplacement within regional domal structures (Ibrahim and Cosgrove, 2001) followed by extension parallel to their fold axes (e.g. Sibai dome, Fowler et al., 2007), and (4) interpreted the Hafafit Complex as a result of fold interference patterns involving multiply deformed sheath folds (Fowler and El Kalioubi, 2002). The aim of this study is to examine the zircon morphology of the gneissic granitoids intruding the five domes of Hafafit Culmination and relate them with the different evolution events of Hafafit Culmination.

\section{Geological Setting}

The rock assemblages in the Wadi Hafafit Culmination (WHC) (latitudes $24^{\circ} 35^{\prime} 00^{\prime \prime} \mathrm{N}$ and $24^{\circ}$ $51^{\prime} 00^{\prime \prime} \mathrm{N}$ and longitudes $34^{\circ} 30^{\prime} 00^{\prime \prime} \mathrm{E}$ and $34^{\circ} 45^{\prime} 00^{\prime \prime} \mathrm{E}$ ) could be grouped into two main units which are separated by Nugrus Thrust which is associated with Nugrus shear zone.

The overlying unit (Nugrus unit) is mainly mode up of low grade mica-schists and metavolcanics that outcrop in eastern and northern part of the WHC. This unit is associated with remnants of serpentines altered ultramafic rocks and metagabbros. The underlying unit (Hafafit unit) is composed of tonalities, granodiorites and quartz diorite, it has been subdivided into five separated gneissic domes (labeled A-E core gneisses; of various areal extend (El Ramly and Greiling, 1988) (Figure 1). The basement rocks of the domes consist of banded amphibolites, overthrusted by ultramafic rocks, alternating bands of biotite- and hornblende-gneisses and psammitic gneiss at the rim of the domal structure. In some parts, the amphibolites are associated with metagabbro (Abd El-Naby and Frisch, 2006). Granitoids (tonalites granodiorites and quartz diorites) with gneissic texture intrude the cores of the domes. Tonalite prevails in the core of the northernmost dome (dome A), where the peripheral zone is strongly foliated and encloses conformable bands of foliated metagabbro. In places, the tonalite is intruded by numerous, thin pegmatite veins giving the erroneous impression of migmatites. Stern and Hedge (1985) gave an age of 680 Ma for the tonalite. In the outer rim of the core, tonalite is also intruded by pegmatite veins; it acquires a conspicuous white colour which is accentuated by the weathering and kaolinization of oligoclase. At the northern part of the dome, highly altered, irregularly-shaped, small masses of rusty brown serpentinite are enclosed in metavolcanic rocks. They are transformed along the peripheries of the intruding pegmatite veins into fibrous anthophyllite (Rasmy, 1974). The domes B and C, occupy the central eastern part of Hafafit unit. These outcrops include migmatitic rocks intruded by gneissic granitoid of tonalite and granodiorite composition with diffuse and irregular gradual

$\underline{\text { XLVII, No } 1-439}$ 
contacts. Migmatites and gneissic granite are surrounded by amphibolitic metagabbro and intruded later by leucogranite. Dome D occupying the central western part of Hafafit unit is a more elongated dome relative to the other domes. The core of this dome consists of gneissic tonalite and granodiorite while in the rim gneissic quartz diorite surrounded by foliated metagabbro is present. The contact between gneissic granite and foliated metagabbro is gradational. Dome E occupies the southern part of Hafafit unit. The core of this dome consists of gneissic tonalite surrounded by foliated metagabbro. The contact between gneissic tonalite and foliated metagabbro is a clear sharp contact; tonalite intrudes the metagabbro. Both units (Nugrus and Hafafit unit) have been intruded by undeformed leucogranites, especially along thrust zones.

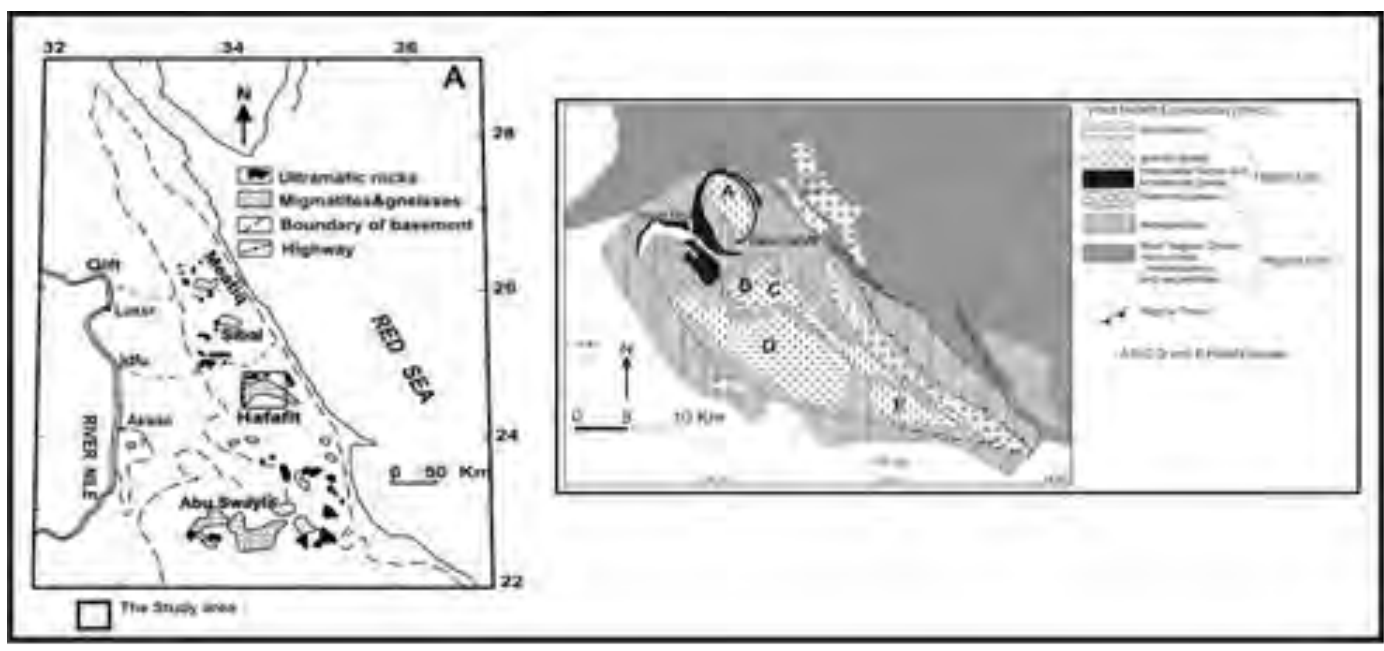

Figure 1 - Simplified geological map of the Wadi Hafafit area showing the main rock types, and structures. (Modified after EI Ramly etal., 1993).

\section{Petrography of the Hafafit Unit Granitoid Rocks}

A brief petrographic description of the different granitoid rocks intruding the cores of Hafafit unit domes is given bellow:

\subsection{Tonalites}

Tonalites occupy the cores of all the Hafafit domes. They are composed of quartz, plagioclase, hornblende, and biotite as the main minerals and sphene, zircon and opaques are the accessories. Chlorite and epidote are secondary constituents. The tonalites are medium to coarse grained weakly to moderately deformed and show a gneissic texture marked by the parallel alignment of hornblende and biotite. Plagioclase shows lamellar twinning. It is weakly to moderately deformed with the twin lamellae sometimes curved. It is sometimes zoned except tonalite of dome E that is strongly deformed and altered to epidote. The single crystal of plagioclase shows deformation band and deformation twin. Quartz occurs as anhedral aggregates interstitial to the plagioclase and it is sometimes slightly elongated. It exhibits moderate deformation as indicated by the undulose extinction. This deformation is more abundant in the samples occurring near the faults planes. Biotite is dark brown in color forming tabular crystals and flakes marking the foliation planes. It is often altered to chlorite. Hornblende forming prismatic crystals is green to dark green in color. It is often associated with biotite, chlorite, opaque minerals and sphene. Rarely, large crystals of magnetite mineral exist in the tonalites, which may be inherited from the source rock. Zircon occurs as euhedral and subhedral prismatic crystals ranging in length from 0.03 to $0.25 \mathrm{~mm}$ and width from 0.010 to $0.1 \mathrm{~mm}$. They are always included in biotite, plagioclase, hornblende and quartz. Apatite occurs mainly in dome D as long prism ranging in length from 0.03 to $0.14 \mathrm{~mm}$ 
and in width from 0.02 to $0.06 \mathrm{~mm}$. It appears as inclusions in hornblende and plagioclase. Magnetite occurs along hornblende cleavage planes in tonalites of dome D. Tonalites are characterized by high content of quartz which increases towards the rim of the domes. Biotite is more abundant close to the core and decreases towards the periphery whereas hornblende exhibits reverse relation. The deformation is more intense at the rims of domes compared to the cores.

\subsection{Granodiorites}

Granodiorites occupy the cores of the domes B, C and D where they intrude tonalites. They are composed mainly by quartz, plagioclase, K-feldspar, biotite and hornblende. Garnet, opaques, apatite and zircon are accessories whereas chlorite and epidote are secondary constituents. They are coarse-grained, foliated rocks showing hypidomorphic texture. The subparallel arrangement of biotite and hornblende forms a gneissic texture. Plagioclase is the dominating mineral. It occurs as subhedral to euhedral tabular crystals ranging from 1.4 to $7 \mathrm{~mm}$ in length and from 1.5 to $3.7 \mathrm{~mm}$ in width. Plagioclase crystals are corroded by quartz. They generally show lamellar twinning. Sometimes, plagioclase crystals are partially or completely altered to epidote. Quartz is found as subhedral to anhedral crystals of various shapes ranging in size from 1.5 to $5.8 \mathrm{~mm}$ in length and from 0.6 to $3.1 \mathrm{~mm}$ in width while quartz of granodiorites of domes B and C are characterized by undulose extinction. K-feldspar is mainly represented by microcline and microcline microperthite occuring as subhedral coarse crystals up to $5 \mathrm{~mm}$ across. It shows cross-hatch twinning with fine streaks of albite giving the perthitic texture. Biotite occurs as fine to medium, slightly curved to highly kinked, irregular flakes foliated between plagioclase and quartz. They are rarely altered to chlorite and iron oxides. Hornblende occurs as subhedral prisms. It ranges from 0.8 to $4.8 \mathrm{~mm}$ in length and from 1 to $2.3 \mathrm{~mm}$ in width. Hornblende crystals are pleochroic from pale to dark green. Zircon occurs as euhedral prismatic crystals; its length ranges from 0.030 to $0.1 \mathrm{~mm}$ and width ranges from 0.010 to $0.070 \mathrm{~mm}$. It occurs as inclusions in biotite, plagioclase and quartz. Sometimes it occurs as bipyramidal crystals with smaller size. Apatite is rare as inclusion in biotite but occurs as long prismatic crystals. Magnetite fill the cracks of quartz as well as the cleavage planes of biotite and often surround biotite crystals.

\subsection{Quartz Diorite}

Quartz diorite occupies the outer part of tonalites of dome D. They are well foliated; they are sometimes strongly deformed showing gneissic texture. They are composed of plagioclase, quartz, biotite and hornblende. Accessory minerals are opaque, sphene and zircon. Plagioclase occurs as subhedral to anhedral crystals moderately to strongly sericitized or kaolinized. Some plagioclase crystals are corroded by quartz and show lamellar twining with the twin lamellae inclined to the foliation planes, moreover it has intense deformation and this is clear in deformation band and deformation twin. Quartz forms anhedral intercalated aggregates interstitial to the plagioclase. It is strongly deformed and shows partial recrystallization. Biotite is present in small amounts associated with hornblende. Biotite occurs as fine to medium, slightly curved to highly kinked, irregular flakes with brown to dark brown colour. Sometimes is partially altered to chlorite and contains inclusions of apatite, zircon and magnetite. Hornblende is green in colour, forming xenomorphic crystals often replaced by biotite. Sphene exists as irregular and sphenoid subhedral crystals corroded by quartz and biotite. The majority of sphene crystals appear to surround opaques. Zircon forms euhedral and subhedral normally prismatic and long prismatic crystals enclosed mainly in hornblende, plagioclase and quartz.

\section{Zircon Morphology}

Zircons from a particular rock type at different domes have distinctive characteristics (e.g. habit, elongation, colour and inclusions). For example, the very wide range of shapes, sizes, colours and other features shown by their zircon crystals characterize the host granitoid rocks. Alper and

$\underline{\text { XLVII, No } 1 \text { - } 441}$ 
Poldervaart (1957), Larsen and Poldervaart (1961), Spotts (1962), Zav'yalova et al. (1966), Forbes (1969) and Thabet (2008) show that the zircon features can be used as supporting evidence for establishing genetic relationships among geographically separated but chemically related igneous rocks. The systematic morphological study of each zircon crystal can be achieved through detailed investigation and determination of the following features (Figures 2 and 3 and tables 1 to 3 ):

\subsection{Colour and Inclusions}

The groups of the zircon crystals, of the studied Hafafit granitoids domes, distinguished on the basis of their colour are given in table land Figure 3A. Taking into account the proportion of crystals in each group it must be noted that the group of coloured zircons is more common in tonalite of dome E (Figure 2F) while colorless zircons are common in all domes A, B, C and D. Quartz diorite of dome D contains mainly colourless zircons.

Opaque minerals are found as inclusions in zircon crystals. They are present as irregular, regular and parallel to $c$-axis. They are characterized by dark brown to black colour. The grouping of the zircon crystals, distinguished on the basis of their inclusions is presented in Table 1and Figure 3B.

Some zircon crystals contain smaller zircon crystals as inclusions. This phenomenon being more common in domes $\mathrm{A}$ and $\mathrm{D}$, implies that the granitoids of domes $\mathrm{A}$ and $\mathrm{D}$ have two zircon generations; the first generation has magmatic features while the second generation has post magmatic features. The orientation of $\mathrm{C}$-axis of zircon crystals of the two generations is SE-NW being parallel to the main dominated lineation of hosting minerals (plagioclase, hornblende and biotite).

\subsection{Crystal Length, Crystal Breadth and Elongation Ratio}

The length of zircon crystals is usually measured along the $c$-axis. According to the length they have been distinguished in four groups (Table 1and Figure 3C). The short and the normally zircon crystal groups are the most frequent in all the studied domes. In all domes the majority of the zircon crystals (over $80 \%$ ) are short while less than $20 \%$ are normally long. Long zircons are rare, only in tonalite of dome A and tonalite and granodiorite of dome D while very long zircons are absent.

Crystal breadth is measured along the $a$-axis of the crystal. The Hafafit zircons granitoids domes, have been distinguished in four groups (Table 2 and Figure 3D). Normally thick zircons are more abundant in domes A, D and E, very thick zircons are recorded only in tonalite of dome A and in all rock types of dome $\mathrm{D}$.

The elongation ratio of a zircon crystal is the ratio of the length (L) over the breadth (B), L/B. According to the values determined, the zircon can be distinguished in four groups (Larsen and Poldervaart 1961) presented in table 2 and Figure 3E. It is clear that in tonalite of dome A, 38.55\% of the zircons are normally elongated, $33.73 \%$ stout, $19.27 \%$ elongated and $8.43 \%$ highly elongated. Tonalite and granodiorite of domes B\&C have $53.65 \%$ normally elongated zircons, $43.90 \%$ stout, $2.43 \%$ elongated while highly elongated zircons are absent. Tonalite of dome $\mathrm{E}$ has $38.46 \%$ normally elongated zircons, $57.69 \%$ stout, 3.84\% elongated; highly elongated zircons are absent as well. Tonalite and granodiorite of dome D have $33.63 \%$ normally elongated zircons, $42.72 \%$ stout, $19.7 \%$ elongated, and $4.54 \%$ highly elongated. Quartz diorite of dome D has $23.07 \%$ normally elongated zircons, $63.46 \%$ stout, $13.46 \%$ elongated and no highly elongated. The above observations can be summarized as following:

1. The normally elongated zircon crystals are the most common in the Hafafit granitoid domes $\mathrm{A}$ and $\mathrm{B} \& \mathrm{C}$ rocks.

2. The highly elongated zircon crystals are recorded only in tonalite of dome A and in tonalite, and granodiorite of dome D.

3. The stout zircon crystals are frequent in tonalite of dome $\mathrm{E}$ and in quartz diorite of dome $\mathrm{D}$. 
Granitic rocks contain mostly normally elongated zircons (elongation ratio 2.0-3.0, Larsen and Poldervaart, 1961; Forbes, 1969); unusual in that respect are granites with relatively high proportions of stubby crystals $(\mathrm{L} / \mathrm{B}<2.0)$ or of highly elongated crystals $(\mathrm{L} / \mathrm{B}>4.0)$. Tonalites in general have mostly elongated zircons (L/B 3.0-4.0) and especially with L/B from 3.2.
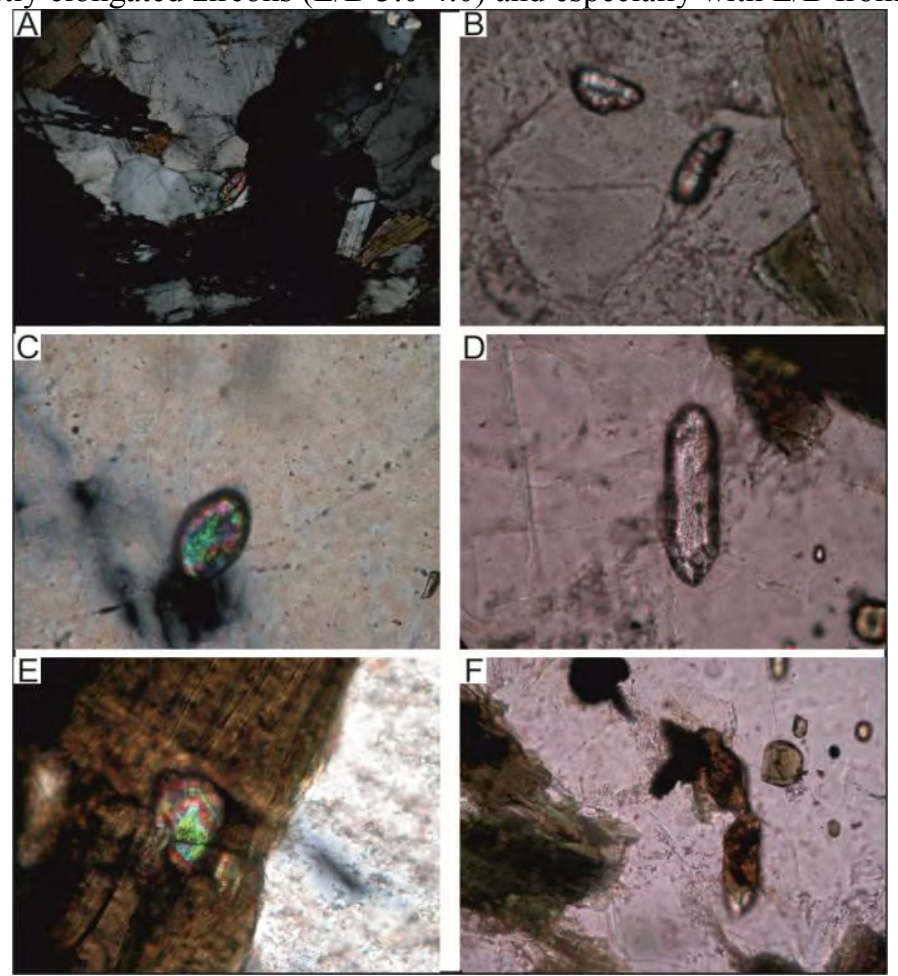

Figure 2 - Photomicrographs shows a) euhedral zircon combining prism with bipyramids found as inclusions in quartz (dome A), B) quartz hosting sub-rounded zircon long prism with primary evolution bipyramid has inclusion of opaques (dome A), C) euhedral zircon combining short prism with bipyramid found as inclusions in quartz (Dome B), D) plagioclase hosting euhedral zircon show combination of long prism and bipyramid, this zircon have inclusions of zircon and opaques (dome D), e) euhedral zoned core zircon combining short, thick prism with bipyramid found as inclusions in sheared biotite flakes (dome D), f) quartz hosting brown euhedral zircon show combination prism with bipyramid and also hosting of short prism colorless zircon (dome $E$ ).

\subsection{Crystal Forms and Habits}

The individual simple forms in which frequently the zircon crystals occur are:

i) Tetragonal prism $\{110\}$, ii) Tetragonal bipyramid "ordinary bipyramid" $\{111\}$, iii) Steep bipyramid $\{331\}$, iv) Basal pinacoid $\{001\}$ and v) Single basal plane (pedion).

In any rock, zircons are generally characterized by different forms and habits, depending upon the relative development of prism with respect to the bipyramid. These habits can be described as:

1. Short stubby zircons: where the crystals are short prismatic and mostly with bipyramidal development.

2. Normally prismatic zircons: where the crystals are prismatic bipyramidal but the prism is moderately developed.

3. Long prismatic zircons: where the crystals are prismatic with bipyramidal but the prism is high developed. 
4. Bipyramidal prismatic zircons: where the bipyramid is dominated and constitute about twothird of the crystal length. The crystal is consequently spindle-shaped.

The percentages of the zircon crystals, of the studied Hafafit granitoids domes, distinguished on the basis of their habit are given in table 2 and Figure 3F. The short stubby zircons are more common in tonalite and granodiorite of domes $\mathrm{B} \& \mathrm{C}$ rather than other domes (Figure 2C). The normally prismatic zircons dominate in all domes but they are more common in tonalite of dome E. The long prismatic zircons are more common in tonalite of dome A (Figure 2A) and in tonalite and granodiorite of dome D (Figure 2D). Bipyramidal prismatic zircons are recorded only in tonalite and granodiorite of dome $\mathrm{D}$ (Figure 2E). The alkali-granites can be distinguished from all other granites by the long-prismatic habit of their zircons. It is noteworthy that long-prismatic zircons are equally unusual in both alkaline and calc-alkaline rocks. Moreover, the prismatic habit is supplanted by a bipyramidal habit in many peralkaline rocks (Wyatt, 1954).

\subsection{Degree of Roundness and Corrosion}

The zircon crystals are distinguished in three groups on the basis of their edges and corners as follows:

1. Angular (or Euhedral) zircons, where the corners and edges of the crystals are sharp.

2. Subrounded zircons, where the crystals show considerable wear and the bipyramidal terminations show pronounced rounding, but the prism and most of the pyramidal faces still persist.

3. Rounded zircons, where the prism faces are smoothly curved and the pyramid terminations are rounded. The degree of roundness is a natural feature, most probably due to magmatic resorptions or might be produced during cooling of magma (Spotts, 1962). The percentages of the zircon crystals, of the studied Hafafit granitoids domes, distinguished on the basis of their degree of roundness are given in table 3 and Figure 3G. Tonalite of dome A has $83.13 \%$ euhedral zircon crystals, $14.45 \%$ subrounded crystals and $2.40 \%$ rounded crystals. Tonalite and granodiorite of domes B\&C have $53.65 \%$ euhedral crystals $46.34 \%$ subrounded crystals while rounded crystals are absent. Tonalite of dome E has $46.15 \%$ euhedral zircon cystals, 53.84\% subrounded crystals and rounded zircon crystals are absent as well. Tonalite and granodiorite of dome D have $63.63 \%$ euhedral zircon crystals, $31.81 \%$ subrounded crystals and $4.54 \%$ rounded crystals. Quartz diorite of dome D has $78.84 \%$ euhedral crystals, $19.23 \%$ subrounded crystals and $1.92 \%$ rounded crystals.

\section{Discussion and Conclusions}

Empirical studies by Pupin (1980) infer that the morphology of zircon reflects the source characteristics of host granitoids. Vavra (1990, 1993), Benisek and Finger (1993) and (Thabet, 2008) conclude that the morphologies of zircon crystals could only reflect the latest stages of granitoids evolution. The study of morphological characteristics of zircon crystals from different Hafafit domes concluded that coloured zircons is more common in tonalite of dome E, while colorless zircons are common in all domes A, B, C and D. Quartz diorite of dome D contains mainly colourless zircons. Mostly zircon of all domes is angular and sub-rounded crystal, the distribution of length and habit of zircon crystal show that domes $\mathrm{A}$ and $\mathrm{D}$ have long zircons and long prismatic zircons but domes $\mathrm{B}, \mathrm{C}$ and $\mathrm{E}$ have high common short long zircon and short stubby habit. The long prismatic crystals are prismatic with bipyramidal but the prism is high developed. Bipyramidal prismatic zircons have the bipyramid, which dominates and constitutes about two-thirds of the crystal length. The crystal is consequently spindle-shaped. This means that domes $\mathrm{A}$ and $\mathrm{D}$ exposed to late regional extension and zircons are oriented SE-NW according to the general late orogenic extension. Some zircon crystals contain smaller zircon crystals as inclusions. This phenomenon being more common in domes $\mathrm{A}$ and $\mathrm{D}$, implies that the granitoids of domes $\mathrm{A}$ and $\mathrm{D}$ have two zircon generations; the first generation has magmatic features while 

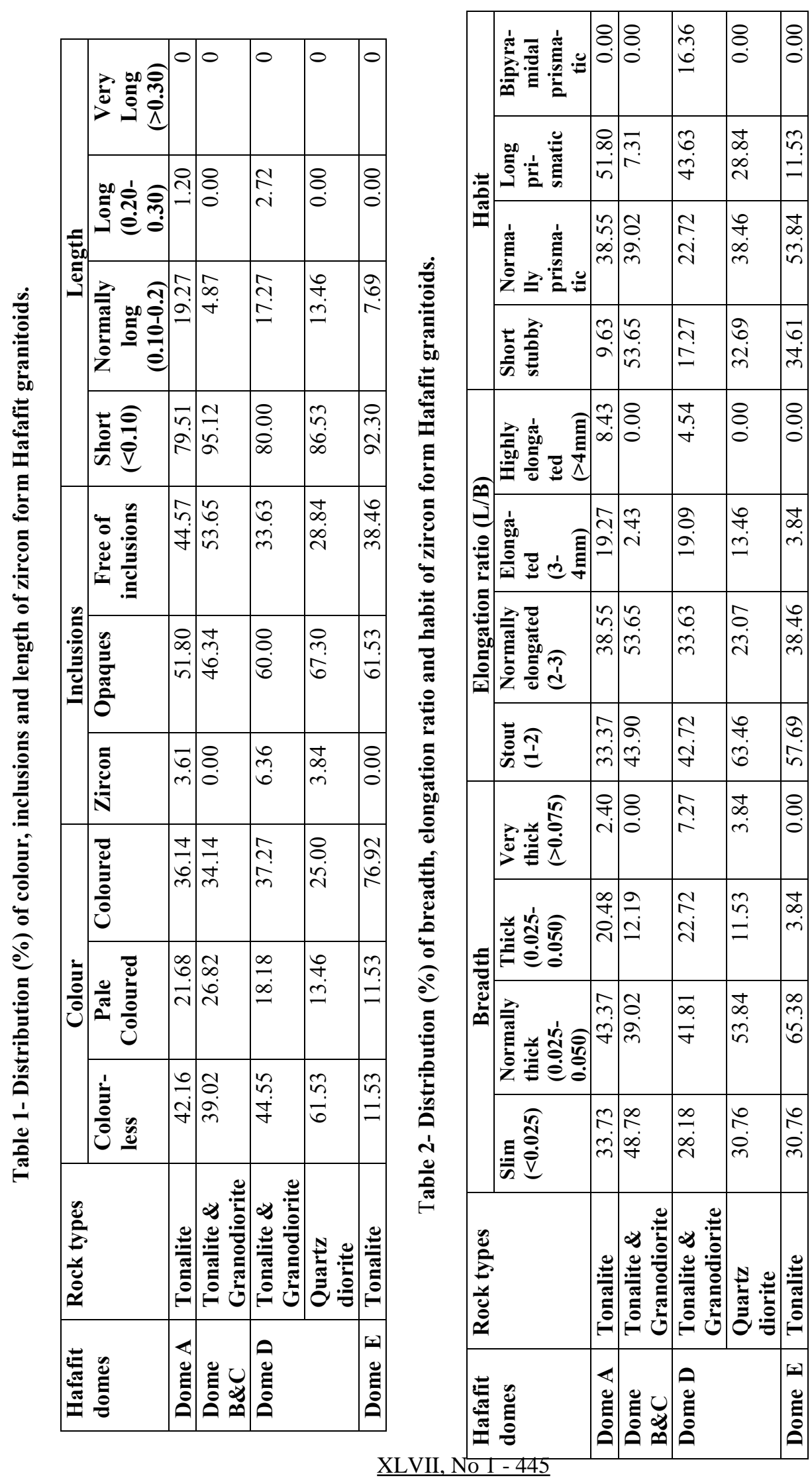
Table 3- Distribution (\%) of different roundness of zircon form Hafafit granitoids.

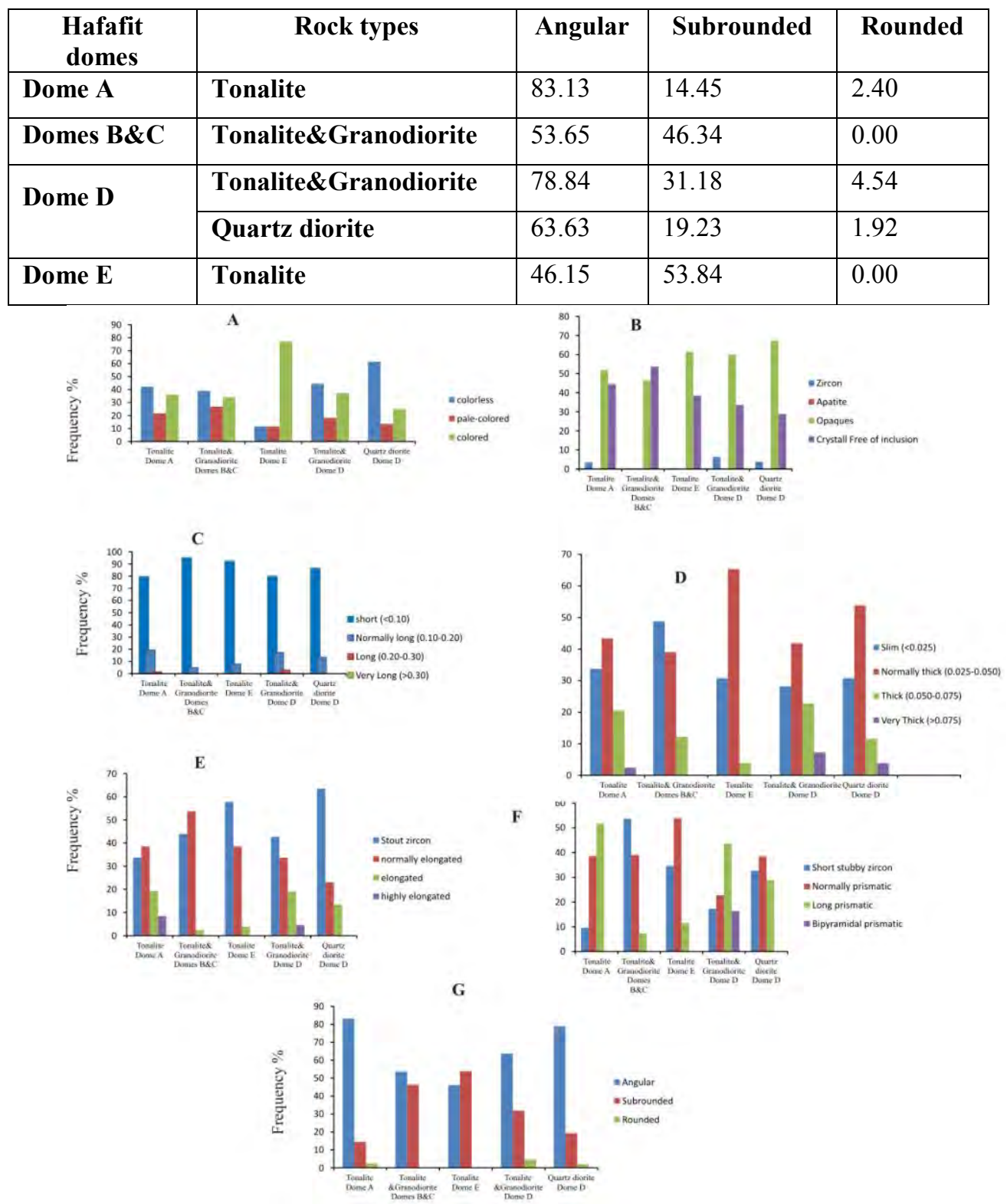

Figure 3 - Histograms showing the distribution (\%) of different morphological characters of zircon crystals from Hafafit granitoids as A) color, B) inclusion, C) length, D) breadth, E) elongation ratio, $F$ ) habit $G$ ) degree of roundness.

the second generation has post magmatic features. The orientation of C-axis of zircon crystals of the two generations is SE-NW being parallel to the main dominated lineation of hosting minerals (plagioclase, hornblende and biotite). The first generation of zircon is attributed to the subduction, magmatic and deformation events while the second generation of zircon is attributed to metamorphism. However, C-axes of zircon crystals of the two generations are parallel to the main dominated lineation of hosting minerals (plagioclase, hornblende and biotite) and oriented SENW. The Wadi Hafafit culmination can be described by three events (Abd El Naby et al., 2008):

1. Subduction, magmatism and deformation event. 
2. Metamorphism.

3. Orogenic extension oriented SE-NW.

According to Kroner et al. (1994) the zircon ages of granite samples from dome D yielded two $\mathrm{Pb}^{207} / \mathrm{Pb}^{206}$ ages $698 \pm 14 \mathrm{Ma}$ and $677 \pm 9 \mathrm{Ma}$ which are in agreement with the two zircon generations distinguished in the present study. Taking into account the zircon morphological characteristics, we attribute the first generation (magmatic zircon) with the age of magmatism, (698 Ma) and the second one (post magmatic zircon) with the age of 677 Ma representing the metamorphic event. Finally, the SE-NW orogenic extension oriented both generations parallel to the trend of the left-lateral shear zone of Najd fault system.

\section{Acknowledgments}

Our thanks are due to Greece Scholarships Foundation (IKY) for supporting the doctoral studies in Aristotle University Thessaloniki (Greece) our thanks are also Professor Mohamed Abdel Wahed for helping in field work.

\section{References}

Abd El Naby H., Frisch W. and Siebel W. 2008. Tectono-metamorphic evolution of the Wadi Hafafit Culmination (Central Eastern Desert, Egypt), Implication for Neoproterzoic core complex exhumation in NE Africa, Geologica Acta, 6, 4, 293-312.

Abd El-Naby H. and Frisch W. 2006. Geochemical constraints from the Hafafit Metamorphic Complex (HMC): evidence of Neoproterozoic back-arc basin development in the central Eastern Desert of Egypt, Journal of African Earth Science, 45, 173-186.

Abdel Wahed M. 2008. Thrusting and transpressional shearing in the Pan-African nappe southwest ElSibai core complex, Central Eastern Desert, Egypt, Journal of African Earth Science, 50, 16-36.

Alper A.M. and Poldervaart A. 1957. Zircons from the Animas stock and associated rocks, New Mexico, Economic Geology, 52, 952-971.

Benisek A. and Finger F. 1993. Factors controlling the development of prism faces in granite zircons: a microprobe study, Contribution Mineralogy and Petrology, 114, 441-445.

Bregar M., Bauernhofer A., Pelz K., Kloetzli U., Fritz H. and Neumayr P. 2002. A late neoproterozoic magmatic core complex in the Eastern Desert of Egypt; emplacement of granitoids in a wrenchtectonic setting, Precambrian Research, 118, 59-82.

El Bahariya G. A. and Abd El-Wahed M. A. 2003. Petrology, mineral chemistry and tectonic evolution of the northern part of Wadi Hafafit Area, Eastern Desert, Egypt, The $3^{\text {rd }}$ international Conference on the Geology of Africa, Assiut, Egypt, 2, 201-231.

El Bahariya G.A. 2008. Geology and petrology of neoproterozoic syntectonic anatectic migmatites around Wadi Abu Higlig, Hafafit region, Eastern Desert, Egypt, Egyptian Journal of Geology, 52, 25-54.

El Ramly M.F. and Greiling R. 1988. Wadi Hafafit Area-1:100,000 Geology map, Technische Fachhoochschule, Berlin.

El Ramly M.F., Greiling R.O., Rashwan A.A. and Rasmy A.H. 1993. Explanatory note to accompany the geological and structural maps of Wadi Hafafit area, Eastern Desert of Egypt, Geological Survey of Egypt, Paper No. 68.

Forbes W.C. 1969. Zircons of the White Mountain magma series: Belknai mountain complex, American Mineralology, 54, 787-795.

Fowler A. and El Kalioubi B. 2002. The Migif-Hafafit gneissic complex of the Egyptian Eastern Desert: fold interference patterns involving multiply deformed sheath folds, Tectonophysics, $346,247-275$.

Fowler A.R., Khamees H. and Dowidar H. 2007. El Sibai gneissic complex, Central Eastern Desert, Egypt: Folded nappes and syn-kinematic gneissic granitoid sheets-not a core complex, Journal of African Earth Science, 49(4), 119-135.

Fritz H., Dalmeyer D. R., Wallbrecher E., Loizenbauer J., Hoinkes G., Neumayr P. and Khudeir A.A. 2002. Neoproterozoic tectonothermal evolution of the Central Eastern Desert, Egypt: a 
slow velocity tectonic process of core complex exhumation, Journal of African Earth Science, 34, 543-576.

Fritz H., Wallbrecher E., Khudier A.A., Abu El Ela F. and Dallmeyer R.D. 1996. Formation of Neoproterozoic metamorphic core complexes during oblique convegence, Eastern Desert, Egypt, Journal of African Earth Science, 23, 311-329.

Greiling R.O., El Ramly M., El akhal H. and Stern R. J. 1988a. Tectonic evolution of the northwestern Red Sea margin as related to basement structure, in: The Gulf of Suez and Red Sea Rifting, X. Le Pichon and J.R. Cochran (eds.), Tectonophysics, 153, 179-191.

Greiling R.O., Kröner A., El-Ramly M. F. and Rashwan A. A.1988b. Structural relationships between the southern and central parts of the Eastern Desert of Egypt: details of a fold and thrust belt, in: El-Gaby S, Greiling RO (eds) The Pan-African belt of NE Africa and Adjacent Areas, Earth Evolution Science, Vieweg, 121-145.

Ibrahim S. and Cosgrove J. 2001. Structural and tectonic evolution of the Umm Gheig/El-Shush region, central Eastern Desert of Egypt, Journal of African Earth Sciences, 33, 199-209.

Khudeir A., Abu El-Rus M., El-Gaby, S., El-Nady O. and Bishara, W. 2008. Sr-Nd isotopes and geochemistry of the infrastructural rocks in the Meatiq and Hafafit core complexes, Eastern Desert, Egypt: evidence for involvement of pre-Neoproterozoic crust in the growth of Arabian-Nubian Shield Island Arc, 17, 90-108.

Kröner A., Kruger J. and Rashwan A.A. 1994. Age and tectonic setting of granitoid gneisses in the Eastern Desert of Egypt and southwest Sinai, Geologische Rundschau, 83,502-513.

Larsen L.H. and Poldervaart A. 1961. Petrologic study of Bald Rock Batholith, near Bidwell Bar, California, Geological Society American Bulletin, 72, 69-92.

Loizenbauer J., Wallbrecher E., Fritz H., Neumayr P., Khudeir A.A. and Kloetzil U. 2001. Structural geology, single zircon ages and fluid inclusion studies of the Meatiq metamorphic core complex implications for Neoproterozoic tectonics in the Eastern Desert of Egypt, Precambrian Research, 110, 357-383.

Pupin J.P. 1980. Zircon and granite petrology, Contributions Mineralogy and Petrology, 73, 207-220.

Rashwan A.A. 1991. Petrography, geochemistry and petrogenesis of the Migif-Hafafit gneisses at Hafafit mine area, South Eastern Desert, Egypt, Science. Series. Internnational. Bureau, Volume 5, Forschangszentran Julich GmbH, pp. 359.

Rasmy A.H. 1974. Petrological, mineralogical and genetic studies of the Hafafit pegmatites and related mineralization, Ph.D thesis, Faculty of Science Ain Shams Univ., Cairo.

Shalaby A. 2009. The northern dome of Wadi Hafafit culmination,Eastern Desert, Egypt. Structural setting in tectonic framework of a scissor-like wrench corridor, Journal of African Earth Science.

Spotts J.H. 1962. Zircon and other accessories minerals, Coast Range Batholith, California, Geological Society American Bulletin, 73, 1221-1239.

Stern R.J. and Hedge C.E. 1985. Geochronologic and isotopic constraints on Late Precambrian crustal evolution in the Eastern Desert of Egypt, Geology Society American Bulletin 28, 97-127.

Thabet I.A. 2008. Petrogenetic implication of zircon as guide to physicochemical conditions of emplacement and crystallization of hosting rocks, M.Sc. thesis, Faculty of Science Tanta Univ., Tanta, Egypt.

Vavra G. 1990. On the kinematics of zircon growth and its petrogenetic significance: a cathode luminescence study, Contributions Mineralogy and Petrology, 106, 90-99.

Vavra G. 1993. A guide to quantitative morphology of accessory zircon, Chemical Geology, 110, 15-28.

Wallbrecher E., Fritz H., Khudeir A. A. and Farahat F. 1993. Kinematics of Pan-African thrusting and extension in Egypt. In: Thorweihe U, Schandehneier H (eds) Geoscientific Research in Northeast Africa, Balkema, Rotterdam, 27-30.

Wyatt M.1954. Zircon as provenance indicators, American Journal of Mineralogy, 39, (No. 1112), 983-990.

Zav'yalova I.V., Vasilenko V.B. and Dorosh V.M. 1966. Correlation of habits of accessory zircon from the Eastern Transbaikal granitic rocks, Geology geofiz, 10, 112-115. 